\title{
OS EFEITOS DA SOCIALIZAÇÃO POLÍTICA DE UM SINDICALISMO “APOLÍTICO”: UM ESTUDO DE CASO
}

KAREL YON ${ }^{\mathrm{I}}$

RESUMO: Com base em um estudo de caso que permite o desenvolvimento de uma análise processual do engajamento no interior da Confederação Francesa Força Operária (Force Ouvrière), o artigo apresenta uma discussão sobre os efeitos da socialização política de um engajamento militante que se legitima tomando distância da política. A pesquisa demonstra como a desconfiança política pode, sucessivamente, facilitar ou dificultar a carreira sindical e, em seguida, como as relaçóes interpessoais e aprendizados militantes conduzem à emergência de um progressivo interesse pela política. $O$ ponto de vista sindical a partir do qual os agentes constroem sua relação com o mundo da política torna, contudo, improvável a satisfaçáo desse "desejo de política” diante da oferta político-partidária existente.

Palavras-chave: Sindicalismo. Engajamento. Socialização. Politização. França.

\section{THE POLITICAL SOCIALIZATION EFFECTS OF "APOLITICAL" UNIONISM: A CASE STUDY}

ABSTRACT: Drawing on a case study, the article develops a processual analysis of the commitment in the French labor confederation Force ouvrière. It interrogates the political socialization effects of an activist commitment that takes its legitimacy by distancing itself from politics. It shows how political defiance, first facilitates, then impedes a unionist's career. It also shows how union learning and socializing develops an increasing interest towards politics. However, the union standpoint from which social agents build their relationship to the political world makes highly improbable that the existing political parties be seen as a satisfactory response.

Keywords: Trade unionism. Commitment. Socialization. Politicization. France.

${ }^{1}$ Université de Lille/CNRS - Villeneuve-d'Ascq, France. E-mail: karel.yon@univ-lille2.fr DOI: 10.1590/ES0101-73302016166645 


\title{
LES EFFETS DE SOCIALISATION POLITIQUE D'UN SYNDICALISME «APOLITIQUE»: UNE ETUDE DE CAS
}

\begin{abstract}
RÉSUMÉ: À partir d'une étude de cas permettant de développer une analyse processuelle de l'engagement au sein de la Confédération Force Ouvrière, l'article s'interroge sur les effets de socialisation politique d'un engagement militant qui se légitime dans la mise à distance de la politique. Il montre comment la défiance politique peut successivement faciliter et entraver la carrière syndicale, puis comment les fréquentations et apprentissages militants conduisent à faire émerger un intérêt accru pour la politique. Le point de vue syndical à partir duquel les agents construisent leur rapport au monde politique rend cependant improbable la satisfaction de ce "désir de politique» par l'offre partisane existante.
\end{abstract}

Mots-clés: Syndicalisme. Engagement. Socialisation. Politisation. France.

\section{Introdução}

A

$s$ teorias clássicas do sindicalismo dão à formação de sindicatos diferentes explicaçóes. Dependendo da escola, a filiação sindical serve integração a uma comunidade profissional ou constitui a expressão da consciência e da luta de classes. Na França, devido à história e ao peso da CGT no movimento sindical, também por causa das características do sistema de relaçóes profissionais, que promove um sindicalismo militante e reivindicativo mais que de serviços, o engajamento sindical tem sido, há muito tempo, entendido principalmente como a expressão do conflito de classes. Entretanto, essa leitura está longe de esgotar a realidade do sindicalismo. O pluralismo do campo sindical, sua realidade diferenciada de acordo com os lugares, permite, de fato, uma ampla variedade de práticas. Mais do que escolher a priori entre uma ou outra dessas teorias, a sociologia política do sindicalismo propóe, como consequência, partir do sentido que os próprios atores atribuem a suas práticas. Estudar o engajamento sindical implica, desse modo, em documentar empiricamente os diversos interesses que os indivíduos dedicam à atividade sindical e na maneira em que ela, por sua vez, os transforma. Assim, o engajamento é visto como um processo dialético ao longo do qual os atores moldam a organização do mesmo modo em que são moldados por ela. Trata-se, em outras palavras, de encarar como um processo de socialização, formado por uma sucessão de fases de aprendizagem e de redefinição de si que levam, emprestando um conceito do interacionismo simbólico, a verdadeiras "carreiras militantes" (FILLIEULE, 2001). 
Daniel Gaxie (1978) mostrou que o engajamento militante, político ou sindical, contribuía fortemente à socialização política: para os indivíduos oriundos das classes populares, serve para adquirir o capital cultural de substituição que lhes permite manipular a linguagem política. No entanto, o mesmo autor também mostrou, e com ele Pierre Bourdieu (1979), que a competência política, entendida como a capacidade de operar uma construção realmente política no espaço político, era apenas uma soma de conhecimentos abstratos e capacidades intelectuais. É também uma competência estatutária em que a mobilização depende do sentimento de sua própria legitimidade. A socializaçáo política implica, desse modo, não só a aquisição de saberes, mas também a capacidade prática, socialmente autorizada, de falar ou fazer política, o que exige o desenvolvimento de verdadeiras inclinaçóes e a formação de um "gosto" para a política. Esse modo de entender a socialização política tem uma consequência no retorno à habilidade política: já não pode ser considerada apenas como uma quantidade mensurável; também deve ser entendida qualitativamente. Os agentes não se satisfazem em adquirir instrumentos para orientar-se ou agir em um mundo político que existia antes deles; eles literalmente "constroem seu mundo político" e sua relação com o mesmo a partir dos padróes de pensamentos e de ação que eles aprendem a mobilizar durante seu engajamento (GAXIE, 2002). Portanto, estudar a socialização política, dessa forma, supóe dar igual atenção às propriedades dos indivíduos e das configurações organizacionais concretas a que se dedicam.

Estendendo essa visão praxiológica, outros pesquisadores demonstraram que as lógicas práticas de mobilização da competência política não dependiam apenas das disposiçôes internalizadas, mas também das situaçôes. Assim, podemos nos considerar politicamente competentes sem nos sentir autorizados, em certos contextos, a mobilizar a linguagem política. Nina Eliasoph, nos EUA (1998), e Camille Hamidi, na França (2010), descrevem os ativistas e voluntários que passam mais tempo a evitar a política que a realizá-la. Foi o que também observei dentro da Confederação Sindical Força Operária (Force Ouvrière) (YON, 2008; 2009): em muitas situaçóes, os militantes que observei, entrevistei ou encontrei nos arquivos esclareceram que eles nunca fazem política no sindicato, o que não impediu muitos deles de serem, por outro lado, membros de um partido ou de terem opinião política. Nas reuniôes sindicais, encontros ou conferências dos quais participei, eles proibiam qualquer discussão que parecesse muito abstrata, ideológica ou distante do campo marcado das reivindicaçóes econômicas e sociais. Quando um militante violava essa regra, ele era, de acordo com a gravidade do insulto ou formalidade da situação, ignorado, recebido por um silêncio constrangedor, firmemente repreendido ou tranquilamente "colocado de volta em seu lugar" em tom de brincadeira. Essa regra de distanciamento da política era amplamente aceita e os militantes justificavam essa cautela pelo fato de que, o que distingue o sindicato de um partido, é justamente que ele deve reunir todos os trabalhadores, independentemente de suas opinióes políticas. 
Como o engajamento pode desenvolver a competência política dos indivíduos, incentivando-os a manter distância da política? E, acima de tudo, quais são as consequências de tal ambivalência sobre sua relaçáo com a política? Por causa de suas escolhas empíricas e metodológicas, os trabalhos sobre o distanciamento da política fornecem respostas à primeira pergunta, mas sáo menos relevantes para responder à segunda. Concentrando-se nos engajamentos contemporâneos abordados pela observação etnográfica, essas pesquisas podem justificar mais facilmente o desvio de um problema de socialização política (dos indivíduos) para a politização (das situaçóes), que se concentram em atores e grupos apreendidos em um curto espaço de tempo. Os ensinamentos militantes podem, no entanto, deixar uma impressão duradoura, tanto se operados intensamente em ambientes onde as pessoas vivem por e para o seu engajamento, constituindo, desse modo, verdadeiros habitus militantes (YON, 2005), quanto se implantados de forma contínua ao longo de várias décadas, como no caso de um militantismo sindical praticado ao longo de toda a vida profissional. Compreender esses processos de longa duraçáo envolve um retorno ao material clássico para estudar carreiras militantes: a história de vida. A história de vida faz com que seja possível restaurar um caminho de aprendizagem e, especialmente, conectar o engajamento sindical, em suas diferentes fases, ao que as pessoas enfrentam em outras esferas da vida.

Por meio de um estudo de caso, eu gostaria de destacar a ambivalência política da socialização sindical. A aquisição dos papéis sindicais conduz à internalização de competências que, potencialmente, "enfraquecem" politicamente os indivíduos. Enquanto isso, a relação com a política, ao mesmo tempo crítica (no questionamento de objetos rotulados como políticos) e monarquista (na aceitaçáo de uma delimitação do sindicalismo na área restrita da economia), que delimita o engajamento sindical, pode "enfraquecê-los" politicamente. O resultado é um sistema de disposiçóes contrárias à política. Embora eu não tenha mencionado no artigo, o dispositivo de pesquisa que embasa minha reflexão é obviamente maior. Ele articula dados de entrevistas e dados quantitativos recolhidos por questionário, observaçóes etnográficas e pesquisas em arquivos. Os dados estatísticos, em particular, me permitiram atualizar os grupos militantes de acordo com as propriedades e as lógicas de engajamento ali comparadas. São esses resultados que me permitem considerar a trajetória individual apresentada nesse artigo como emblemática do que constitui o principal efeito da socialização sindical entre os grupos mais recentes de militantes FO: a produção de um "civismo desiludido"1.

Mostrarei, em primeiro lugar, de que maneira o distanciamento da política permite uma forma de legitimação negativa da ação sindical, porque entra em ressonância com percepçóes negativas da política amplamente disseminada entre os leigos. Em uma segunda etapa da carreira militante, a desconfiança política pode, contudo, ser contraproducente: uma vez iniciada uma trajetória de engajamento que vai além do nível local e/ou profissional, o significado das diferenças 
entre sindicalismo e política deve, na verdade, ser reorganizado para que os agentes resistam à assimilação espontânea das formas sindical e partidária. Em seguida, mostrarei como o engajamento sindical fornece recursos relacionais, práticos e simbólicos suscetíveis ao surgimento de um aumento de interesse pela política. Mas a lógica pela qual os agentes avaliam o mundo político, se é relevante do ponto de vista da atividade sindical, torna improvável a satisfação desse "desejo político" pela oferta partidária existente.

\section{O distanciamento político como início de uma "carreira desconfiada"}

A socialização familiar de Christine, com quarenta e poucos anos no momento da pesquisa, náo a levou à ação coletiva ${ }^{2}$. Seu pai, mecânico, tornou-se policial pouco antes de maio de 68. Sua mãe, depois de ter trabalhado no campo, ficou em casa para cuidar de suas três filhas. A família, entre funcionários e operários, sempre conviveu com a "mão direita" do Estado (BOURDIEU, 1998): de ambos os lados, antes de seu pai, os homens tinham tentado integrar a polícia. $\mathrm{O}$ universo familiar é totalmente alheio à ação coletiva ("meu pai nunca foi sindicalizado, nem formado politicamente..."). Os preceitos que parecem guiar a família referem-se, primeiramente, à arte de o indivíduo "se virar" ("meu pai sempre nos disse se alguém enchesse nosso saco era para meter a mão na cara"). Depois de iniciar a faculdade de direito em uma pequena universidade do interior (escolhida também pelo tamanho mais "familiar"), Christine interrompeu seus estudos em 1986 para seguir seu namorado que, após terminar um curso técnico, foi trabalhar em Paris. Não sendo mais estudante, ela acabou seguindo os passos do pai e prestou um concurso para guarda policial, em 1989. Ela fez seu primeiro contato com o sindicalismo em uma relação de extrema necessidade, depois que um militante permitiu-lhe adiantar sua integração à academia de polícia. É porque ela sentiu-se em dívida direta com ele que ela filia-se, no início dos anos 1990, ao Sindicato Geral de Polícia (SGP), ainda que tenha sido, a princípio, muito hostil aos sindicatos, que ela compara aos partidos:

Então, no início, eu, como todo mundo, em relação aos sindicatos, eu fazia uma mistura entre sindicatos / partidos políticos. E eu não queria, de jeito nenhum, ouvir falar de sindicato, porque eu achava que eram partidos políticos, era realmente... muito delimitado, você entra lá dentro, é como na escola militar, coisas assim.

Incentivada, como uma jovem mulher, a assumir responsabilidades sindicais, ela começa a integrar, em 1993, o escritório do SGP e torna-se, então, membro permanente do sindicato. Pouco tempo depois, será secretária de uma seção do departamento, e logo secretária regional. A velocidade, não só de sua 
entrada para o sindicalismo, mas também de sua profissionalização, relaciona-se com as novas perspectivas que parecem tê-la levado ao militantismo. Ela diz que rapidamente começou a gostar das responsabilidades sindicais e das diversas atividades com as quais se envolveu nesse contexto ("Eu gosto de mudar de setor porque eu gosto de aprender"). Em particular, ela assumiu a responsabilidade do jornal sindical. Todo o talento que ela desenvolveu por meio do sindicalismo parece compensar suas esperanças frustradas de realização profissional. Ela me disse que queria ter seguido carreira na área jurídica (advogado ou juiz) ou no jornalismo. Ela já havia, inclusive, trabalhado no jornal dos estudantes da sua universidade. Christine parece ter sido capaz de transferir para o mundo sindical a disposição que queria ter tido nos estudos, se não tivesse abandonado seu curso. Ela enfatiza a mobilidade que o sindicalismo lhe garante: ele circula, encontra pessoas, especialmente durante as eleiçóes profissionais. Tudo indica que o engajamento sindical surgiu como uma parte inesperada de auto-realizaçáo. Se a escolha de continuar no sindicalismo foi forçada pela lógica do estigma profissional (" $n o$ SGP era: 'você é permanente, você não prestou concurso'. Porque mesmo se você prestasse e você passasse, diriam que foi o sindicato que te ajudou"), essa restrição encontra-se, assim, transformada em uma oportunidade, uma vez que o sindicalismo abriu-lhe horizontes mais amplos que o seu trabalho na polícia. Entre o conhecimento adquirido graças ao militantismo sindical, o domínio da fala é o que a impressiona mais nos dirigentes sindicais:

E é verdade que, inicialmente, no escritório do SGP, eu estava completamente espantada, porque a mulher lá, [...] ela escrevia duas palavras no papel, e entáo ela fazia um discurso de uma hora. Eu perguntei a ela, mas como você faz isso? [Risos] como você faz o que? Ela me dizia, uma hora virá, com um pouco de experiência sindical. A partir do momento em que você dominar o assunto, é verdade, você é capaz de ficar falando durante horas.

Não só o sindicalismo parece mais desejável do que uma profissão com a qual ela admite ter se irritado logo nos primeiros anos, mas talvez seja também o que mais se ajusta a seus talentos. De fato, ela teve que prestar duas vezes sua prova final de ensino médio, admite ter problemas com a ortografia e se sentir muito mais confortável com os esportes - o que, inclusive, foi uma parte importante da preparação para o concurso da polícia. Ela poderia ter passado no concurso de inspetor de polícia com o seu diploma de graduação, mas ela disse que preferiu o de guarda para "começar na base". Vários sinais perceptíveis de uma relação difícil com o universo escolar. A carreira sindical pareceu permitir um desenvolvimento que não se baseia em critérios de excelência escolar, inclusive nas atividades intelectuais normalmente associadas a esses critérios (mobilização prática do direito para defender os colegas, falar em público, elaboração de um jornal). 


\section{Neutralizando a analogia entre as linguagens sindical e política}

Em meados de 1990, o SGP é um membro da Federação Autônoma dos Sindicatos de Polícia, que é filiado à Uniāo Nacional dos Sindicatos Autônomos ${ }^{3}$. Nesse contexto, a distância política apresenta-se, na época, sob o nome de "autonomia". Esse princípio é retransmitido quando o SGP filia-se à FO no final da década. Se a autonomia marcava a diferença dos sindicatos em relação aos partidos, a dependência federativa parece levantar o espectro da tutela política:

Assim é a história da integração à $\mathrm{FO}$, porque é nossa culpa, não foi bem explicado aos nossos militantes e, também, para a maioria dos nossos militantes de base, tanto a FO como a CGT e a CFDT, são muito subordinadas a um partido político. [...] Qual é a imagem do cidadão comum? O que ele vê? Ele vê TV, ele vê a CGT. E ele vê a CGT, e ele coloca todos no mesmo saco. Com a gente foi parecido. Se fosse a FO seria parecido, com a CGT seria ainda pior, já que está mais marcada politicamente. Então nós fazíamos essa confusão assim como o cidadão comum.

A “politização" está, provavelmente, ainda mais marcada na CGT porque é duplamente visível: por um lado, por causa da história de suas relaçóes estreitas com o PCF; por outro, na medida em que as práticas e tomadas de posição de seus militantes entram, com mais frequência, em dissonância com a ordem legal. Essas representaçóes negativas da CGT, portanto, irradiam sobre as outras organizaçóes representativas na assimilação da forma confederativa à forma partidária.

Identificar-se com uma organização supóe que seu pertencimento a ela foi suficientemente estabilizado para assegurar um contato "de confiança" com os níveis menos familiares da estrutura, nesse caso, a descoberta da realidade multidisciplinar. Em um contexto geral de descrédito da categoria "partido", a retórica da independência, central no discurso legítimo para a FO, mostra aqui toda sua ambivalência. Ela pode legitimar o engajamento sindical, na dupla distância da política que proporciona, de um lado, a distinção das categorias "sindicato" e "partido" e, de outro, o horizonte de ação imediato, local, concreto, que o ativismo profissional oferece (o modo mais comum de entrada no sindicalismo ${ }^{4}$ ), segundo o qual a atividade política aparece como um universo de práticas distantes. Porém, depois de permitida a entrada em uma carreira militante, pode contrariar sua duração quando chega a hora de ligar esse engajamento local à dimensão mais ampla do movimento. A partir desse ponto de vista, os cursos de formação sindical desempenham um papel decisivo na socialização à nova organização, na medida em que combinam a possibilidade de momentos intensos de sociabilidade com um ensino explícito de boas razóes para atuar na instituição, desarmando as interpretações "erradas". Assim, Christine lembra-se do papel da formação na evolução de seu ponto de vista sobre integração à $\mathrm{FO}$ : 
[Os estágios de formação] realmente, é uma escola de emancipação de militantes. Francamente, te dáo todas as ferramentas, por outro lado, te ajudam a entender um monte de coisas que você não compreendia [...]. Mas eu, na primeira vez, quando fomos informados que iriam aderir à FO, eu era completamente contra. Porque eu tinha essa imagem de partido político. E então quando você vai aos estágios, você vê que não é nada disso. Que realmente, a CGT-FO, porque não é FO, é a CGT-FO, sempre foi um sindicato ou presa a esse princípio de independência frente aos partidos políticos e essa noção de liberdade.

O caso dos estágios de formação sindical sublinha bem o caráter inseparavelmente cognitivo e social da socialização sindical. A mobilização das boas categorias de percepçáo aparece, necessariamente, apoiada pelo substrato social que facilita sua incorporação: o incentivo dos militantes que respeitamos, a riqueza das novas reunióes de militantes, a sociabilidade eficaz que se atualiza, se descobre ou se reforça na ocasião dessas reunióes.

Desse modo, a formação contribui fortemente para a ideologização do engajamento (ETHUIN, 2003). A reorganização da relação com o mundo passa, entáo, pela aceitação de novos recortes da realidade social e de novas palavras para descrevê-la. Tal como o seu engajamento sindical envolvia distinguir "sindicato" de "partido", o que Christine fala sobre sua aceitação gradual dos termos "camarada" e "luta de classes" mostra que se trata mais de adaptar sua compreensão do mundo a essas categorias que de livrá-las, de antemão, do conteúdo negativo que ela lhes atribuía, comparando-as ao "comunismo":

no início, quando o apresentador nos chamava de camarada, quando ele nos falava sobre a luta de classes... Eu pensei caramba aonde eu vim parar? Estou aqui com os comunistas? Várias vezes e, depois, bem eu era da SGP mas, mesmo no estágio, tinha estagiários que se olhavam e diziam, mas o que ele está fazendo com a gente, nós estamos onde aqui? Bem, isso é tudo. Não dizíamos mais nada, e depois bem todos nós entendemos quando na quinta de manhã ele nos contou a história. Explicando que o termo 'camarada' não tinha nada a ver com o comunismo, já que vem do companheirismo, do século XVI, então os comunistas não existiam na época e, bem, era companheiro de quarto, era mais um conceito de camaradagem e de compartilhar a mesma luta. Então, isso necessariamente náo me chocou. No meu sindicato, não é um termo que eu vou usar. Vamos chamar de 'companheiros', vamos chamar de 'amigos', coisas assim. Entre nós, entre militantes, vamos chamar de 'camarada', mas quando fizermos reunióes de informação onde você tem colegas, você não vai dizer isso, porque eles não vão entender. E então você vai perder tempo explicando o termo histórico. E eu não tenho certeza de que vão entender. Porque se você já começar pelo 
'camarada' eles não vão te ouvir, com certeza. Então, eles nos explicaram, depois, a luta de classes, bem, ele explicou, é assim: são duas classes que têm interesses diferentes, então, obviamente, há luta, embora não necessariamente luta [cerrando o punho] eles brigam, nãoooo. Existem alguns interesses diferentes e, então, na verdade cada um faz de maneira que, bem, defendem seus interesses, sua classe, seus interesses de classe.

Esse testemunho mostra como, ao longo do estágio, os facilitadores mudam o "campo conotativo" de signos anteriormente considerados negativos (HALL, 2007). A reduçáo do "movimento operário" ao sindicalismo, e a contenção da atividade sindical (os "interesses de classe") ao domínio econômico, permitem rearticular esses termos em um sistema simbólico compatível com a desconfiança de Christine em relação ao mundo político, em geral, e ao comunismo, especificamente.

Como este processo envolve um trabalho sobre si mesmo, estritamente intelectual, de reorganização de seu relacionamento com o mundo, ele produz entre os agentes a consciência de sua própria competência para operar ativamente construçōes simbólicas do mundo social, ou seja, abstraçôes. É o que aponta Christine quando se lembra de sua primeira inquietação, gradualmente dissipada pela internalização do discurso e dos modos de raciocínio da instituição sindical. Vendo-se, inicialmente, como parte desses "policiais ignorantes", ela percebe que ela e seus colegas não são menos capazes do que outros militantes de orientar-se em debates abstratos:

E é verdade que é muito interessante, porque, bem, do ponto de vista humano é interessante, mas também em termos de conteúdo, é super interessante. Para contar outra história: quando houve a integração eles nos deram uma formação, então, bem, tem os membros do escritório e depois alguns regionais do SGP, da França e de Navarra, e por isso era no Breviário [o centro de formação da Confederação]. Por isso, tivemos a nossa formaçáo, e depois no Breviário tinha outro estágio. Eu não lembro mais que estágio. E na quinta à noite tinha um debate que reunia os estagiários dos dois grupos. E aquele que tinha vindo fazer o debate, era o René Valladon [responsável da confederação], e ele falou sobre o imposto Tobin ou o petro-dólar, eu não sei mais, algo do tipo. Estávamos ouvindo, mas não entendíamos nada! Nós pensávamos, mas realmente somos ignorantes, somos realmente retardados mentais, somos completamente ignorantes, não entendíamos nada. E, depois, víamos os outros militantes que eram de outras áreas, que náo eram muito intelectualmente melhores que nós, não é isso, mas que entendiam, que faziam perguntas, havia trocas, coisas assim. E então nós pensávamos, mas caramba, nós somos realmente retardados, somos os policiais idiotas. E depois, bem, obviamente, você recebe o FO semanal, você não lê tudo, mas você lê certo número de coisas, você as- 
siste a conferências, participa de reunióes e, bem, gradualmente os termos ficam cada vez mais familiares e, depois, você tem a impressão de entender um pouco melhor. E então, nos estágios seguintes, você pode participar mais. Então, para explicar melhor, realmente a FO é realmente uma escola de emancipação dos militantes, que permite, no limite, compreender os termos que você vê do lado de fora, que não estáo, necessariamente, na sua profissão, então isso abre a sua mente.

O discurso sindical evita o receio dos militantes que não querem "fazer política" ao promover a tolerância entre os indivíduos com ideias opostas. A internalização da ideologia sindical, como "estrutura estruturante" (BOURDIEU, 1977), oferece aos atores um conteúdo (um discurso sobre o mundo) e habilidades (capacidade de abstraçáo), que permitem que eles se localizem no mundo social. As interaçóes sindicais contribuem para desenvolver disposiçôes para a reflexão em geral, inclusive em questóes (como a taxa Tobin) que poderiam, anteriormente, ter parecido extremamente distantes das preocupaçóes concretas (relacionadas à "profissão") desse militante.

\section{Profissionalização sindical, companhias militantes e reavaliação da política}

Se os militantes apropriam-se das habilidades cognitivas que resumimos no termo "ideologia sindical"s, é precisamente porque sua natureza sindical facilita, para alguns, a aquisição desses valores de referência, ou seja, porque eles estão em negação de seu caráter potencialmente "político". A ativação dessas habilidades sindicais permite, por sua vez, que os agentes questionem o sentimento de incompetência que eles sentiram em relaçáo a um mundo político inicialmente percebido como distante e abstrato. Apesar de um discurso que desqualifica fortemente o mundo político especializado, é assim que a socialização sindical pode levantar, entre os militantes, um novo interesse pela política. Interesse que, por sua vez, estimula novos contatos, à medida que os agentes evoluem em sua carreira sindical. É o que Christine mostra com sua trajetória, sendo a ocasião de encontros e oportunidades de investimento político. São os encontros ocasionados por seu engajamento sindical que, claramente, a familiarizaram com a política, na pessoa de um ex-líder do SGP. Ele apresentou-a ao Partido Socialista de um modo nada ideológico: tratava-se de "dar uma mão" quando ele foi ameaçado de perder sua seção; ela tinha ido lá como um amiga, em uma lógica que faz eco com seu encontro inicial com o sindicalismo. É em contato com esse representante sindical, o qual sentimos ser um modelo para Christine, que a política pôde ser reabilitada a seus olhos, até na reavaliação - aceita com relutância - do qualificador como uma qualidade ('muitas vezes ele me dizia 'seja politica Christine, seja politica...' mas eu 
não estou nem aí com a sua política, não me enche com isso!'). No entanto, se a ideia de engajar-se na política só tornou-se possível por meio do exemplo desse dirigente, seu universo de referência profissional ainda vai impedir a passagem ao ato, elucidando, por sua vez, a que ponto o engajamento sindical pôde ser facilitado pelo desdobramento inicial nessa área restrita às questóes "corporativas":

Houve momentos, especialmente quando o PS estava com problemas em 95, que eu me perguntei se eu náo iria aderir ao PS, mas em outros momentos, inclusive quando víamos em programas de TV deputados do PS, francamente era muito pouco provável, no estilo Leroux, o prefeito de Epinay, que em certo momento foi questionado para fazer não sei qual relatório sobre a segurança e que, muito pedante, foi explicar para você como fazer seu próprio trabalho. Ou mesmo Dray, que eu tive que encontrar, também em um programa de TV, que disse que não havia necessidade de tantos policiais, que não tinha necessidade de um policial atrás de cada habitante, teve a cara de pau para dizer que pedir muito efetivo era porque éramos completamente fascistas... [...] Então é verdade que quando eu vi caras assim, eu pensei o que você quer ir fazer nessa bagunça, são todos exmembros da ENA (Escola Nacional de Administração) lá dentro, todos sabem mais do que você, você não pode acrescentar nada.

O mundo da polícia parece, assim, incompatível com o universo tradicional de ancoragem da esquerda, como mostra a difícil relação de Christine com os professores:

na escola, quando preenchíamos pequenas fichas dizendo o que nossos pais fazem, e eu colocava policial e, bem, eu sofria muitas críticas. Porque, em geral, na época em que fiz os meus estudos, os professores não gostavam muito da polícia. Houve até mesmo um professor, na época, que me disse que náo gostava dos policiais. Então eu disse a ele, bem, meu pai também não ia gostar de você. E então eu sempre sofri um pouco isso.

Essa relação difícil com a esquerda e seus representantes típicos não implica, ao mesmo tempo, um posicionamento político de direita. Christine diz, por exemplo, que seus pais votaram em François Mitterrand (o presidente da República socialista de 1981-1995), mesmo que sua mãe gostasse mais de Jacques Chirac, o candidato de direita que ganhou as eleiçóes presidenciais de 1995 e 2002. Ela mesma admite ter votado, quando mais jovem, em Jacques Chirac, mas agora ela vota na esquerda. Da mesma forma, em sua apresentaçáo do trabalho de policial, ela valoriza o lado preventivo, que ela associa, implicitamente, a uma visão "de esquerda". Essa visão se opóe ao discurso dominante da profissão, que relaciona a esquerda ao laxismo, o que não o impede de mobilizar esse discurso na multidão, sem parecer constrangido pela incoerência de suas afirmações: "De qualquer forma aqui, isso está 
claro. Quando a esquerda está no poder, o cidadão é o rei e o queridinho das cidades, quando é a direita é o oposto. Com... aquele que é tolo não há meio-termo".

O desconforto não existe na medida em que a dissonância cognitiva está confinada à ordem do discurso: ela é limitada à expressão de opiniōes divergentes. Porém, é justamente porque essas opiniōes se referem à existência de tendências contrárias à política que elas constituem um sério obstáculo ao compromisso partidário. Assim, a socialização sindical pôde levantar a proibição contra os partidos e melhorar a compreensão do universo político, mas sua socialização profissional continua a dificultar a realização da filiação partidária. É a partir dessa contradição que podemos compreender o engajamento de Christine com a franco-maçonaria desde 1998. O aspecto ritualístico das práticas maçônicas não parece entusiasmá-la muito ("o simbólico me irrita"). Ela as associa, pelo contrário, a uma função "cidadâ" claramente afirmada: "eu entrei para a maçonaria a partir do trabalho dos maçons, ou seja, trabalhar juntos para o progresso do universo, isto é, a nivel social, coisas assim. Para mover a sociedade para frente na direção certa".

O engajamento maçônico, se pudesse ter sido um substituto para o engajamento político ainda impensável, não teria interrompido por tanto tempo sua politização. Ao longo de sua carreira sindical, Christine se coloca cada vez mais como "de esquerda". Ela, que tinha votado em Jacques Chirac em sua juventude, não pôde fazê-lo em maio de $2002^{6}$, pois "isso [me] faria muito mal". Ela questionou novamente seu engajamento com o PS em 2004-2005. Embora a realizaçáo do ato possa ter sido facilitada pela sua mudança do sindicalismo policial para uma posição permanente no plano multidisciplinar (que fica separado, em outra união departamental), são os julgamentos sindicais que assumem a postura dos julgamentos profissionais: tornou-se impossível para ela filiar-se ao PS dada sua posição a favor do Tratado Constitucional Europeu, o qual a Confederação FO criticava muito por sua orientação neoliberal. Além disso, ela agora se diz mais de "extrema-esquerda": ela gosta da "Marie-alguma coisa" Buffet e "o carteiro"Besancenot $^{2}$, mas fica incomodada pelo que ele representa. Porque o PC é "o comunismo à moda russa", "o centralismo democrático" e que na "Liga Comunista Revolucionária" (o partido de O. Besancenot), "eles não gostam da polícia, e tudo o que é ligado à segurança". Assim, o sindicato permite ser "de extrema esquerda", sem ser de maneira partidária, porque a escolha de um partido entraria em contradição com certos princípios - sindicais, políticos, profissionais - incorporados, como a desconfiança com o comunismo ou a preocupação com a segurança... A comparação entre essas questôes coletadas em junho de 2005 com aquelas realizadas em uma discussão informal, em fevereiro de 2006, no entanto, mostra a instabilidade de suas referências partidárias. Em 2005, Christine cita a "Liga Comunista Revolucionária" sem problema, o que certamente está relacionado ao contexto do momento: o referendo sobre o Tratado Constitucional Europeu acabara de ser marcado pela campanha a favor do "Não", liderada principalmente pelo PCF e a LCR. Em fevereiro de 2006, ela esqueceu o nome dessa organização. Desse modo, são categorias 
especificamente sindicais que lhe dão apoio para permitir reconstruir o universo partidário: "como se chama, o partido que nasceu da CFDT... tem revolucionário no meio, ou nâo, eu acho... Sim, é isso! LCR!" Se ela situa a LCR, chamando-a pelo nome da organização sindical da qual acha que é mais próxima, é porque é no mundo sindical que ela encontra os recursos de sua informação política.

Tornando-se menos óbvia sua posição dentro da UD tornado-se menos óbvia, ela começou a considerar as possibilidades de uma reconversão "profissional" que ela situa, necessariamente, na esfera do militantismo. Christine confidencia que pretende "fazer política", surpreendendo a si mesma:

Ela deixaria facilmente a união departamental para fazer política, ela gostaria muito de ser eleita nos próximos dez anos. Faz treze anos, desde 1993, que ela participa do sindicalismo, ela aprendeu muitas coisas, mas agora está entediada na UD: "é estranho pensar nisso, eu que era completamente anti-partido antigamente". Por que ela se interessa por eles agora? Ela olha para as leis que são feitas, seria bom se houvessem outras leis, não apenas ficar se opondo... Mas nenhum partido lhe convém. Ela diz ser mais de extrema esquerda. O PS para ela "traiu a classe operária". Ela queria um partido que tivesse peso, que tivesse eleitos, por isso não a LCR. Ela não menciona o PT. Mas nem mesmo o PC, porque ela é contra o comunismo: mesmo que as ideias possam ser boas, são os homens que as aplicam e nós vimos o que eles fizeram na URSS. Ela se questionou sobre os Verdes (o partido ecologista), mas não parece animada. Ela pensou se poderia ser do centro... Pergunto-lhe: na UDF (um partido de centro-direita)? Ela responde que não, nos radicais de esquerda (partido de centro-esquerda). Digo-lhe que eles são eleitos pelo PS, ela diz que não sabe, que ainda vai pensar a respeito.

É o fato de ter sido constantemente verificada a distância de seu engajamento com os partidos que leva a própria Christine a ficar surpresa pelo desejo de fazer política, uma vez que as habilidades, a consciência das mesmas e a inclinação para mobilizá-las foram adquiridas. Ao mesmo tempo, ela combina facilmente um posicionamento na extrema esquerda e a evocação de um partido de centro-esquerda como legendas partidárias possíveis. Mais do que a coerência intrínseca às suas escolhas políticas, são as opinióes contrárias adquiridas durante a sua socialização familiar, sindical, profissional e maçonica (entendemos implicitamente que ela conheceu os radicais de esquerda por intermédio de seu "mentor sindical", o que aconteceu entre o tempo do PS "ao partido radical de direita") que levam à formulação dessa escolha partidária.

Sendo assim, estudo qualitativo do engajamento sindical permite esclarecer o que é essencial para localizar os processos de socialização política, de 
modo a incorporar a ideia de que os saberes e o conhecimento mobilizados pelos agentes fazem sentido a partir de sua posição social. Ela possibilita relacionar paradoxos dos trabalhos sobre a politização, que veem a oposição dos pontos de vista "cognitivista" (a política como "aumento dos conflitos") e "realista" (é considerada política o que os atores designam como tal), mantendo a confusão entre as duas dimensões que são mais articuladas: a socialização, que designa a aquisição de habilidades (práticas, cognitivas, discursivas) e sua qualificação, entendida como a indexação dessas habilidades a universos de significados e de práticas (LAGROYE, 2003). Assim, pareceu-nos útil distinguir os momentos em que as competências adquiridas pela inscrição na instituição sindical podem ser reavaliadas em termos de utilidade para orientar condutas politicas. Essa ideia permite esclarecer aparentes paradoxos, como essas dinâmicas de politização que se negam como tais. A desativação inicial dos prováveis efeitos políticos do engajamento sindical acompanha a crescente aceitaçáo, por Christine, da política como domínio de atividade legítima. Entretanto, essa politização encontra-se, ao mesmo tempo, contrariada. Na medida em que os agentes desenvolvem um interesse pela política a partir de sua posição sindical, pode-se, portanto, compreender a manutenção, no mundo da FO, de uma espécie de "civismo desiludido", que aparece como o resultado de um desajuste entre a estruturaçáo sindical dessa proposta política e o estado da oferta partidária.

\section{Notas}

1. Além da minha tese, eu apresentei esses dados de pesquisa em outro artigo (YON, 2015)

2. Entrevista realizada em 29 de junho de 2005. Eu tentei, na medida do possível, deixar anônimos os dados pessoais.

3. A UNSA é uma união de sindicatos criada em 1993. Náo é reconhecida como representativa pelo Estado em âmbito interprofissional, ela se distingue das cinco organizaçôes que o são porque recusa a forma federativa que considera um entrave à liberdade dos sindicatos profissionais.

4. Duriez e Sawicki (2003) destacam a importância do meio de trabalho como canal privilegiado da adesão sindical e do papel decisivo das sociabilidades militantes na produção progressiva de uma fronteira entre militantes e partidários que as pré-disposiçóes parecem, inicialmente, não distinguir.

5. Falar de uma ideologia sindical relativamente coerente (já que ela se inscreve em uma história objetiva sob a forma de textos doutrinários, status, etc.) não presume, de jeito nenhum, a coerência dos costumes usados pelos indivíduos: esses, pelo contrário, tendem a servir-se disso segundo lógicas práticas, movendo-se na ideologia como em um "stock" ou um "repertório cognitivo" (CORCUFF, 1991). 
6. No segundo turno da eleição presidencial de 2002, Jacques Chirac foi eleito contra o candidato de extrema direita, Jean-Marie Le Pen, depois de um apelo quase unânime no campo político e sindical da frente republicana”. Em nome do distanciamento da política, a FO, de qualquer modo, não votou.

7. Líder do Partido Comunista e candidato às eleiçôes presidenciais de 2002.

8. Candidato de extrema direita às eleiçôes presidenciais de 2002 e 2007, carteiro de profissão.

\section{Referências}

BOURDIEU, P. A distinção: crítica social do julgamento. Paris: Éditions de Minuit, 1979. . A mão esquerda e a mão direita do Estado. In: Contra-incêndio. Paris: Liber-Raisons d'Agir, 1998.p. 9-17. Sobre o poder simbólico. Anais E.S.C., v. 32, n. 3, p. 405-411, 1977.

CORCUFF, P. Elementos de epistemologia básica do sindicalismo. Revista Francesa de Ciências Politicas, v. 41, n. 4, p. 515-536, 1991.

DURIEZ, B.; SAWICKI, F. Rede de sociabilidade e adesão sindical. O caso da CFDT. Politix, v. 16, n. 63, p. 17-51, 2003.

ELIASOPH, N. Evitando a política: como americanos vivem apáticos no dia-a-dia. Cambridge: Cambridge University Press, 1998.

ETHUIN, N. Da ideologização do engajamento comunista. Trechos de uma pesquisa sobre as escolas do PCF (1970-1990).Politix, v.16, n. 63, p. 145-168, 2003.

FILLIEULE, O. Propostas para uma análise processual do engajamento individual: post scriptum. Revue Française de Science Politique, v. 51, n. 1-2, p. 199-215, 2001.

GAXIE, D. Appréhensions du politique et mobilisation des expériences sociales. Revista Francesa de Ciências Políticas, v. 52, n. 2-3, p. 145-178, 2002.

. O censo escondido: desigualdades culturais e segregação política. Paris: Seuil, 1978.

HALL, S. A redescoberta da "ideologia": o retorno do reprimido nos media studies. In: Identidades e culturas: políticas de estudos culturais. Paris: Amsterdam, 2007.p. 81-120.

HAMIDI,C. A sociedade civil nas cidades: engajamento associativo e politização em associaçóes de bairro. Paris: Economica, 2010.

LAGROYE, J. Os processos de politização. In: . (Org.). A politização. Paris: Belin, 2003.p. 359-372.

YON, K. FO em congresso: um observatório da "independência sindical"? Entre valorizaçáo do pluralismo e seletividade dos engajamentos. Socio-logos (On line), n. 11, 2015, publicado em 7 de dezembro de 2015. Disponível em: http://socio-logos.revues. org/3091 Consulta em 13 de julho de 2016. 
Modos de sociabilidade e manutenção do habitus militante. Militar em grupo no AJS-OCI nos anos de 1970. Politix, v. 18, n. 70, p. 137-167, 2005.

Quando o sindicalismo acontece fora do local de trabalho: a produção do significado federativo na 'Force ouvrière'. Politix, v. 22, n. 85, p. 57-79, 2009.

Retorno à relaçóes entre sindicalismo e política: o caso da CGT-FO. Elementos para a sociologia de um "mundo de reflexão". 2008. 852 f. Tese (doutorado) - Departemento de Ciências Políticas, Université Paris 1 Panthéon-Sorbonne, Paris, 2008.

Recebido em 14 de julho de 2016.

Aprovado em 13 de outubro de 2016. 